\title{
EXHAUSTION OF REMEDIES AND WRONGFUL DISCHARGE UNDER THE RAILWAY LABOR ACT
}

The Railway Labor $\mathrm{Act}^{1}$ requires the establishment of a grievance procedure to process disputes arising between carriers operating under the Act and their employees. ${ }^{2}$ Any employee subject to the terms of the Act may use this procedure to test the propriety of his discharge. The Act further provides that should this "on the premises" procedure fail to effect a satisfactory solution, either the employee or the carrier may appeal to the National Railroad Adjustment Board which has jurisdiction to determine whether the discharge was justified. ${ }^{3}$ If it decides that the discharge was wrongful, it may order the carrier to reinstate the employee, either with or without back pay.

At the time of the enactment of these provisions, the availability to such an employee of an action for damages for wrongful discharge was dependent upon the contract law of his state. ${ }^{4}$ The Supreme Court has since been called upon, on several occasions, to settle disputes concerning the impact of the Railway Labor Act upon such common-law actions in those jurisdictions in which they are recognized. Quite early, in Moore v. Illinois Central R. Co., ${ }^{5}$ it was established that state actions for wrongful discharge were not preempted by the Railway Labor Act; and that the federal act did not render the availability of such relief dependent upon a prior exhaustion of the Adjustment Board procedures. ${ }^{6}$ More recently, in Transcontinental \& Western Air, Inc. v. Koppal, ${ }^{7}$ the Court made even more explicit the independence of state law in this area by holding that the Act did not prohibit a state from applying its own doctrine of exhaustion of administrative remedies to such damage actions.

In the wake of the decision in the Koppal case, a number of courts have been confronted with the problem of defining the exhaustion requirements of their respective jurisdictions. ${ }^{8}$ Several states have refused to entertain

144 Stat. 577 (1926), as amended, 45 U.S.C.A. $\$ 151$ (1954).

248 Stat. 1191 (1934), 45 U.S.C.A. \$153(i) (1954).

${ }^{3} 48$ Stat. 1189 (1934), 45 U.S.C.A. $\$ 153$ (1954), provides for the establishment of the Board, sets out its jurisdiction and the procedure for enforcement of awards.

t The essential question was whether an individual employee gained rights of tenure in his employment by virtue of a collective bargaining contract between his union and his employer. On this question, there was disagreement among the states, and this disagreement persists to the present day. See Mathews, Labor Relations and the Law 306-11 (1953).

5312 U.S. 630 (1941).

'In Slocum v. Delaware, L. \& W. R. Co., 339 U.S. 239 (1950), the Court found in the Act a requirement that an employee seeking reinstatement, but not damages, must go to the Board and not to the courts for such relief.

3345 U.S. 653 (1953).

${ }^{8}$ In addition to the cases cited in notes 9 and 10 infra, two states have found that no exhaustion of any kind is required. See Majors v. Thompson, 235 F.2d 449 (C.A.5th, 1956). 
actions for damages where the discharged employee had failed to process his grievance "on the premises."' More recently, it has been beld that the exhaustion of the "on the premises" remedies is not of itself sufficient, and actions have been dismissed for failure to appeal to the Adjustment Board..$^{10}$ These latter cases go further and add, by way of dicta, that decisions of the Adjustment Board are final, thus making that procedure exclusive insofar as employees in those states are concerned. Such decisions are difficult to reconcile with the position implicit in the Moore case that the Adjustment Board was designed to provide such employees with an alternative mode of relief. Although the competence of the states to adopt such a position is confirmed by the Koppal decision, the wisdom of such a course may be open to serious question in view of its inevitable effects upon the rights of the employees involved. It is the purpose of this Comment to examine the rationales which have been offered in support of this position and to evaluate its results.

\section{I}

The earliest case adopting the position that a discharged employee must pursue his claim before the Adjustment Board is Payne v. Pullman Co." In that case, the employee had processed his grievance "on the premises" through the chief operating officer as prescribed by the collective bargaining agreement. After this procedure proved futile he sued for damages in an Illinois state court. In upholding the trial court's dismissal of the complaint, the Illinois Appellate Court relied upon what it referred to as the "doctrine of exhaustion of remedies." The court viewed this doctrine as requiring, in the first instance, an exhaustion of all administrative remedies available to the plaintiff under the Railway Labor Act. ${ }^{12}$ It regarded the creation of the Adjustment Board as providing an administrative forum for the resolution of these disputes, and declared that Illinois law requires resort to such administrative agencies whenever they are available. ${ }^{13}$

Although it regarded the plaintiff's failure to exhaust his administrative remedies as sufficient to justify the decision, the court proceeded to buttress its argument by reference to an entirely separate ground. The court found that the collective bargaining agreement between the carrier and the employee's union, as properly interpreted, made the Adjustment Board the exclusive

${ }^{9}$ Peoples v. Southern Pacific Co., 232 F.2d 707 (C.A.9th, 1956); Breeland v. Southern Pacific Co., 231 F.2d 576 (C.A.9th, 1955); Barker v. Southern Pacific Co., 214 F.2d 918 (C.A.9th, 1954); Borver v. Eastern Airlines, 214 F.2d 623 (C.A.3d, 1954); Ringle v. Transcontinental \& Western Air, Inc., 113 F.Supp. 897 (W.D. Mo., 1953); Stroman v. Atchison, T. \& S.F. Ry. Co., 326 P.2d 155 (Cal. C.A., 1958); Mayfield v. Thompson, 22 S.W.2d 157 (Kan. City, Mo. C.A.; 1953).

${ }^{10}$ Jorgensen v. Pennsylvania R. Co., 25 N.J. 541, 138 A.2d 24 (1958); Payne v. Pullman Co., 13 Ill.App.2d 105, 141 N.E.2d 83 (1957).

" 13 Ill.App.2d 105, 141 N.E.2d 83 (1957).

L2 Id., at 116-17 and 88.

${ }^{13}$ Ibid. 
remedy available to discharged employees.14 Inasmuch as under Illinois law the only rights which the plaintiff could assert in a suit for wrongful discharge were those arising from this agreement, the court concluded that the plaintiff had no rights which a state court could enforce. Thus, plaintiff's case was held to be deficient for the additional reason that he had failed to exhaust his contractual remedies.

Subsequent cases have failed to produce any new justification for the requirement of recourse to the Adjustment Board. ${ }^{15}$ Rather, the courts have been content to rest their argument upon the reasoning of the Payne case. This requirement, insofar as it finds justification in the cases, must rest upon either exhaustion of administrative remedies or exhaustion of contractual remedies. It is submitted that considerable doubt must be entertained as to the applicability of either of these doctrines.

The doctrine of exhaustion of administrative remedies would appear to be totally inapplicable to a suit for damages for wrongful discharge. That doctrine is not ordinarily applied to claims originally enforceable in the courts. Rather it is applied only to those situations in which the courts are requested to intervene in the administrative disposition of a matter originally enforceable by administrative action alone. ${ }^{16}$ That the doctrine as it exists in those jurisdictions requiring resort to the Adjustment Board is no different is clearly illustrated by the cases upon which reliance was placed to establish its vitality. ${ }^{17}$ In none of these cases was the doctrine of exhaustion of administrative remedies utilized to foreclose an action subject to original judicial cognizance.

The doctrine of exhaustion of contractual remedies, as applied to these cases, would appear to be equally lacking in substance. The defect here lies not in the doctrine itself, but, rather, in the fact that its application rests

14 Id., at 117 and 89.

${ }^{16}$ Jorgensen v. Pennsylvania R. Co., 25 N.J. 541, 138 A.2d 24 (1958); Rossa v. Flying Tiger Line, 6 CCH Lab. Law Rep. (4th ed.) \71699 (N.D. Ill., 1958).

${ }^{16} \mathrm{Jaffe}$, Primary Jurisdiction Reconsidered, $102 \mathrm{U}$. of Pa. L. Rev. 577, 579 (1954).

${ }^{17}$ Jorgensen v. Pennsylvania R. Co., 25 N.J. 541, 556-57, 138 A.2d 24, 33 (1958), cites the cases on which the court based New Jersey's exhaustion requirement; Payne v. Pullman Co., 13 II.App.2d 105, 113-14, 141 N.E.2d 83, 87 (1957), cites the Illinois decisions establishing Illinois' exhaustion doctrine. Most of the cases cited by both courts deal only with a general exhaustion doctrine as applied in cases where a party is seeking some extraordinary relief without first applying for legal relief, or involve suits by members of voluntary organizations protesting expulsion from the organization before all internal remedies provided for such instances by the rules of the group are exhausted. None of these cases is applicable to the problem under consideration because the courts are here dealing with an administrative agency, and if any exhaustion doctrine applies, it is the doctrine of exhaustion of administrative remedies. Both the Jorgensen and Payne cases rely on some cases dealing with administrative agencies, but in every instance the statute which established the agency provided for a statutory form of appeal. The doctrine of exhaustion of administrative remedies is properly invoked where then are deviations from the prescribed procedure. The agencies in these case dealt with the rulings of school boards, civil service commissions, zoning boards and utility commissions, all of which concern matters not originally within the cognizance of the courts. 
upon what would seem to be an erroneous interpretation of the facts. Quite clearly, any party asserting contractual rights must bring himself within the terms of his contract, assuming such terms are not violative of public policy. In these cases, however, serious doubts must be entertained that the contracts in question contained provisions which were intended to render the Adjustment Board the exclusive forum for the settlement of these disputes. In the Payne case, for example, the only reference in the contract to the Adjustment Board was a statement that "[a]ny further appeal [after exhaustion of "on the premises" procedure] in accordance with provisions of the Railway Labor Act shall be taken within thirty (30) days from date decision is rendered." 18 The interpretation of this provision as constituting a waiver by the employees of their common-law actions for wrongful discharge certainly is not justified by the language itself. There is nothing to indicate that this provision was intended to do more than limit the time in which an appeal to the Adjustment Board could be taken. It seems quite likely that this provision was included to bar the filing of stale grievances.

Similarly, in Jorgensen v. Pennsylvania $R$. Co., ${ }^{19}$ resort to the Adjustment Board was held to be mandatory, even though the contract in question contained no specific reference to the Adjustment Board, but merely provided for the creation of "on the premises" grievance machinery..$^{20}$ The court reasoned that the provisions setting up this machinery should be read in the light of the Railway Labor Act and, when so read, it became obvious that the contract envisioned a complete plan of arbitrament, both self-sufficient and exclusive. ${ }^{21}$ Such reasoning loses much of its cogency, however, when it is remembered that the Railway Labor Act itself compels the inclusion into these agreements of provisions creating an "on the premises" grievance procedure. ${ }^{22}$

\section{II}

The foregoing analysis suggests that neither the doctrine of exhaustion of administrative remedies nor the doctrine of exhaustion of contractual remedies compels the decision that resort to the Adjustment Board is mandatory. Before concluding, however, that a unique situation is presented which should be determined strictly on its own merits, it must be considered whether there are other doctrines which might compel a conclusion either that resort to the Board is mandatory or that it is unnecessary.

At the outset, an argument which might be regarded as implicit in the opinions of the courts in both the Payne and the Jorgensen cases seems worthy of consideration. In both of those cases citations were made to cases in which it had been held that a member of a voluntary association could not bring

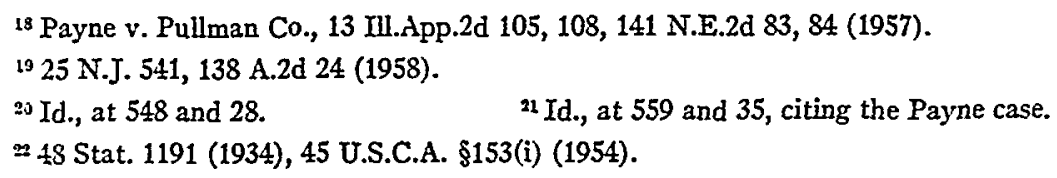


suit for wrongs suffered as a member until he first exhausted any remedies which might be available to him within the organization itself. ${ }^{23}$ An examination of the cases which developed this rule reveals that it was premised upon an implied contract between the member and the association. It could be argued, however, that such a rule rests, in part at least, upon a policy of protecting the courts from suits which could prove both troublesome and unnecessary. As such, the rule could be roughly, but appropriately, described as the doctrine of exhaustion of internal remedies.

The reliance of the courts upon these cases would seem to indicate that suits for wrongful discharge are considered somewhat analogous. It is difficult, however, to isolate an analogy which would justify forcing a discharged employee to appeal to the Adjustment Board. If the cases were cited for their historic rationale, i.e., an implied contract, the citation seems clearly erroneous as has already been pointed out. If, on the other hand, their citation was intended to indicate the presence of a sitution in which the court was being asked to intervene in an internal quarrel, the infirmity seems equally serious. Although such an argument might be put forward with some force to justify mandatory exhaustion of "on the premises" remedies, it would appear wholly inapplicable where the question is appeal to the Adjustment Board. In such cases, the question is not whether there will be intervention by outside parties but, rather, who those parties will be.

Secondly, it might be argued that appeal to the Adjustment Board is required by the doctrine of primary jurisdiction. As pointed out above, the doctrine of exhaustion of administrative remedies is inapplicable to claims over which there is original jurisdiction both in the judiciary and in an administrative body. ${ }^{24}$ But this is precisely the situation in which the doctrine of primary jurisdiction becomes relevant. ${ }^{25}$ Thus, if this doctrine is viewed as resting solely upon considerations of expertise, a view which is not without adherents, an excellent argument would appear to be available to those who would urge that Adjustment Board procedures should be exhausted prior to resort to the courts.

The better view of the doctrine of primary jurisdiction, however, would

${ }^{23}$ Payne v. Pullman Co., 13 Ill.App.2d 105, 113-14, 141 N.E.2d 83, 87 (1957); Jorgensen v. Pennsylvania R. Co., 25 N.J. 541, 556-57, 138 A.2d 24, 33 (1958). See: People ex rel. Michhalowski v. Tanaschuk, 317 Ill.App. 130, 45 N.E.2d 984 (1942); Moody v. Farrington, 227 Ill.App. 40 (1922); Board of Trade of Chicago v. Nelson, 162 III. 431, 44 N.E. 743 (1896); People ex rel. Keefe v. Women's Catholic Order of Foresters, 162 Ill. 78, 44 N.E. 401 (1896); People ex rel. Page v. Chicago Board of Trade, 45 Ill. 112 (1867); Beedie v. IBEW, 25 N.J. Super. 269, 96 A.2d 89 (App.Div., 1953); Naylor v. Harkins, 11 N.J. 435, 94 A.2d 825 (1953); Marchitte v. Central R. Co. of N.J., 9 N.J. 456, 88 A.2d 851 (1952); Siena v. Grande Lodge, 11 N.J.Super. 507, 78 A.2d 610 (App.Div., 1951); Walker v. Pennsylvania-Reading S. Iines, 142 N.J.Eq. 588, 61 A.2d 453 (1948); Dragwa v. Federal Labor Union, 136 N.J.Eq. 172, 41 A.2d 32 (1945); Purcare v. Grand Lodge, 107 N.J.L. 82, 151 Atl. 751 (E. \& A., 1930); Smith v. Ocean Castle, 59 N.J.I. 198, 35 Atl. 917 (E. \& A., 1896).

24 Jaffe, op. cit. supra note 16, at $579 . \quad{ }^{25} \mathrm{Ibid}$. 
seem to produce a different result. Under that view, comparative expertise is not the sole determinative factor. Rather, attention is directed to the policies underlying both the administrative remedy and the judicial remedy and the problem becomes one of the reconciliation of these policies. ${ }^{26}$ Thus, the doctrine would be properly invoked, not when the court felt that the administrative agency was more competent to settle the dispute, but when the court felt that an administrative determination provided the best compromise between the conflicting policies.

Applying this view of the doctrine of primary jurisdiction, the problem presented by a suit for wrongful discharge is easily solved. Judicial settlement of such disputes presents no conflict with the policy of the Railway Labor Act inasmuch as that act was intended to provide the discharged employee with an alternative remedy. ${ }^{27}$ Mandatory resort to the Adjustment Board, on the other hand, does conflict with the policy underlying actions for wrongful discharge for, in effect, it nullifies such actions. The conflict is further exacerbated by the fact that the Adjustment Board cannot offer those remedies which are available under judicial proceedings. ${ }^{28}$ Thus, the inevitable conclusion that the doctrine of primary jurisdiction should not be applied for judicial determination of the dispute provides a perfect reconciliation of both policies.

Finally, one doctrine must be considered which would seem to constrain some states from requiring appeal to the Adjustment Board. Proceedings before the Board are generally regarded as equivalent to arbitration. ${ }^{29}$ This has led to the suggestion that a discharged employee should not be forced to appeal to that body in any jurisdiction which retains the common-law rule prohibiting specific enforcement of agreements to arbitrate future disputes, ${ }^{30}$ and allowing the revocation of such an agreement up to the time an award is made. ${ }^{31}$ The requirement that the employee pursue his claim before the Board, whether as a prerequisite to judicial action or as his exclusive remedy, would constitute a denial of this revocability and, in effect, would give specific enforcement of an agreement to arbitrate a future dispute. The court in the

26 Id., at 581.

${ }^{27}$ Moore v. Ilinois Central R. Co., 312 U.S. 630 (1941).

${ }^{23}$ No provision is made in the Railway Labor Act for the award of damages, and the Adjustment Board has never attempted to award more than reinstatement, with or without back pay.

जo See Chief Justice Warren's discussion of this attribute of the Adjustment Board procedure in Brotherhood of Railroad Trainmen v. Chicago R. \& I.R. Co., 353 U.S. 30, 38-39, (1957).

${ }^{30}$ Selecting a Forum under the RLA for Employer-Employee Disputes in the Airline Industry, 51 Nw. U. L. Rev. 596, 602 (1956). In Sands v. Union Pacific R. Co., 148 F.Supp. 422 (D. Ore., 1956), the court held that a contract provision requiring appeal to the Board did not bar a damage action because such a provision was not enforceable under Oregon common law.

${ }^{11}$ Such is the rule in a majority of jurisdictions, including Illinois, the law of which was applicable in the Payne case. Gregory and Orlikoff, The Enforcement of Labor Arbitration Agreements, 17 U. of Chi. L. Rev. 233, 235-42 (1950). 
Payne case, however, entirely omitted any discussion of the applicability of this doctrine to that case. Although the rejection of this doctrine may be demanded by other considerations of policy, it is submitted that such a result is far from obvious. Rather, the problem presents difficulties ${ }^{32}$ which would seem to merit the closest attention.

\section{III}

In light of the above, it seems fair to conclude that the solution of this problem cannot be deduced from existing doctrine. ${ }^{33}$ Rather, such solution would seem to be possible only after a most careful consideration of the peculiar problems presented. Thus, in order to evaluate the position taken by the court in the Payne case that the Adjustment Board should be the exclusive forum for discharged employees, it would seem necessary to first examine the possible alternative solutions open to the courts. Four alternatives to the Payne solution seem apparent: (1) the employee might be allowed at any time prior to the time when the Board decides to hear the claim to seek damages rather than reinstatement; (2) the employee might be permitted to choose his course of action immediately after discharge, but once having done so could not be allowed to change; (3) the court might require an exhaustion of the "on the premises" remedies, allowing a choice between court action and appeal to the Board if no settlement is reached at the completion of that procedure; and (4) an appeal to the Adjustment Board could be made a prerequisite to a court action.

The obvious virtue of the first alternative is that it gives the employee the greatest amount of freedom in determining how best to prosecute his claim, and to seek reinstatement rather than damages as long as he considered that his most advantageous remedy. Opposing this, however, is the consideration that this gives the employee too liberal a choice, subjects the employer to the necessity of responding to the whim of the employee, handling the

at is, perhaps, reasonable to argue that it is not specific enforcement of an arbitration agreement to refuse to entertain a suit by one who has not complied with the arbirtation provision in the contract which the complaining party claims the other has breached. However, the Illinois case establishing the nonenforceability of agreements to arbitrate future disputes, Cocalis v. Nazlides, 308 III. 152, 139 N.E. 95 (1923), has as its basis the court's belief that to enforce such agreements would deprive the parties of their right to seek relief in the courts. This means, of course, that it is the purpose of the court to allow breach of contract actions in spite of an artibration provision. Even if this argument were not accepted a court could find that appeal to the Adjustment Board is not really an arbitration procedure because the Board is not established by the consensual agreement of the parties but by a federal statute; and if either party decides to resort to the Board the other party cannot refuse to participate in the proceedings.

${ }^{33}$ This statement is, of course, subject to qualification insofar as any state may see fit to allow immediate resort to the courts on the basis of its doctrine of revocability of agreements to arbitrate future disputes. 
case in part, first according to the contract, and then, in court. ${ }^{34}$ In addition, if the employee is allowed to sue in court without even attempting to seek reinstatement, it forces the employer to defend in court the action of a foreman or supervisor which it may consider was ill-advised and would prefer to rectify. ${ }^{35}$

This latter criticism has even a more valid application when it is applied to the second alternative, i.e., that which forces the employee to elect his remedy immediately upon discharge. Assuming the employee decides to sue, the opportunity for negotiation is gone. Also, it is usually beyond the ability of the employee to have knowledge of all the factors which will determine the outcome of any remedy he may pursue, and to foreclose all reconsideration after a step in either direction appears rather harsh.

A requirement that a discharged employee exhaust "on the premises" remedies with a free election upon completion of that procedure has much to commend itself. In the first place, it avoids the inequalities occasioned by the procedural defects ${ }^{36}$ and variations of enforceability ${ }^{37}$ which result from making the Board the exclusive remedy. Nor does it require the parties to go through a procedure which the employee can choose not to be bound by, as is the case with the making the appeal to the Board a prerequisite to a breach-of-contract action. Such a position allows the contesting parties a full opportunity to adjust the dispute between themselves, with the resort to an outside agency allowed only if no settlement can be reached. Because of contract requirements, such a procedure is usually completed within a

34 It must be remembered that the employer also has the right to refer a dispute to the Adjustment Board. The decision in Brotherhood of Railroad Trainmen v. Chicago R. \& I.R Co., 353 U.S. 30 (1957), would seem to indicate that once either party appeals to the Board, the other party is precluded from taking any action while the Board is hearing the case. That case involved a resort by the union to direct action, but the reasoning of the case would seem to be no less applicable to instituting a suit in court.

${ }^{35}$ Of course the carrier could rectify this situation by reinstating the employee, but perhaps it would be unwilling to reinstate an employee who has elected to sue rather than settle the dispute through the grievance procedure. The employee may also decide that he would rather take the chance of obtaining a large verdict rather than just return to his old job.

${ }^{36}$ See: Levinson, Legal Aspects of the NRAB, 4 Lab. L. J. 685 (1953); Northrup and Kahn, Railroad Grievance Machinery, 5 Indust. \& Lab. Rel. Rev. 365, 540 (1952); Railroad Labor Disputes and the National Railroad Adjustment Board, 18 U. of Chi. L. Rev. 303 (1951); Attorney General's Committee on Administrative Procedure, Railway Labor, Sen. Doc. 10, 77th Cong. 1st Sess. (1940). Mr. Justice Reed dissented in Slocum v. Delaware, L. \& W.R. Co., 339 U.S. 239, 251-52 (1950), because he did not feel that the Board should be the exclusive arbitrer of even reinstatement claims on account of its procedural defects. More recently in McKinney v. Missouri-Kansas-Texas R. Co., 357 U.S. 265, 270 (1958), the Supreme Court held that a veteran seeking to vindicate his rights under the Universal Military Training Act with reference to seniority rights upon return to work need not first appeal to the Adjustment Board. A consideration was that Congress did not intend that the veteran would first have to exhaust "lengthy and doubtful procedures" before seeking relief in the courts.

${ }^{37}$ See discussion at 694 infra. 
very short time and, thus, there is no unnecessary delay before a suit can be filed.

The fourth solution, prescribing an appeal to the Board prior to resort to the courts, has at least two advantages over that which makes the Board the exclusive arbiter of such disputes. First, by allowing the employee to sue in court, the effect of the well-known defects characteristic of the Adjustment Board procedure would be mitigated. ${ }^{38}$ Secondly, it compensates somewhat for the inequalities in the enforceability of Board awards which place the employee at a serious disadvantage. If the Adjustment Board decides in favor of the employer, its determination is final subject only to review for due process requirements. ${ }^{39} \mathrm{~A}$ Board decision for the employee, on the other hand, is not endowed with such finality. Such decisions must be enforced by suit in the federal courts where their stature is merely that of prima facie evidence. ${ }^{40}$ In practice the enforceability of Board decisions in favor of the employee depends, in a large number of cases, upon the strength of the employee's union.41 A rule allowing suits for damages after the Board decision would have the virtue of robbing judgments in favor of the employer of their finality, thus reducing them to a status more nearly equal that accorded to judgments obtained by employees.

At the same time, however, this alternative would seem to destroy any justification which might exist for forcing a resort to the Adjustment Board in the first place. ${ }^{42}$ Exclusive reliance upon Board remedies might be defended on the grounds that it relieves the courts of the necessity of deciding a multitude of cases which are both time-consuming and difficult in that they involve issues which require the expertise of a body experienced in such problems. Such a justification becomes inapplicable where the resort to the Board merely delays and does not prevent court action. Thus, it would seem that the same considerations which prompt the rule of exhaustion would demand that the Board's decisions be endowed with as much finality as possible. The difficulty with making the Board the exclusive remedy available to the employee, as suggested in the Payme and Jorgensen cases, is that it gives rise to the very objections which the fourth alternative was designed to overcome..

Thus, on the balance, it would seem that the preferable solution is one in which an exhaustion of "on the premises" remedies was required with

${ }^{38}$ See note 36 supra.

${ }^{39}$ Ellerd v. Southern Pacific R. Co., 241 F.2d 541 (C.A.7th, 1957).

4048 Stat. 1192 (1934), 45 U.S.C.A. \$153(p) (1954).

41 Northrup and Kahn, op. cit. supra note 36, at 541.

22 Even the value of a Board assessment of the merits of the controversy is not very great because many of the cases are settled by inexperienced referees resulting from a deadlocked Board. In addition, such a procedure would result in the continuing influence of a Board decision upon the claim of an employee, the avoidance of which prompted him to seek relief in the courts. 
a free election by the employee at the completion of this process. It is submitted that such a solution offers the greatest benefits at the least sacrifice. This claimed superiority is not, however, so clear that it is beyond debate. The question is sufficiently close to justify variations among different jurisdictions resulting from their individual policies. It does seem clear, however, that the proper solution of this problem in any jurisdiction, depends upon a careful consideration of competing policies. 